MacGregor-Fors, I., J. Quesada, J. G-H. Lee, and P. J. Yeh. 2017. Space invaders: House Sparrow densities along three urban-agricultural landscapes. Avian Conservation and Ecology 12(2):11. https://doi.org/10.5751/ACE-01082-120211

Copyright (C) 2017 by the author(s). Published here under license by the Resilience Alliance.

Research Paper

\title{
Space invaders: House Sparrow densities along three urban- agricultural landscapes
}

\author{
Ian MacGregor-Fors ${ }^{1}$, Javier Quesada ${ }^{2}$, Jeffrey G-H. Lee ${ }^{3}$ and Pamela J. Yeh ${ }^{3}$ \\ ${ }^{1}$ Red de Ambiente y Sustentabilidad, Instituto de Ecología, A.C., Xalapa, Mexico, ${ }^{2}$ Chordates Laboratory, Natural History \\ Museum of Barcelona. Barcelona, Catalonia, Spain, ${ }^{3}$ Department of Ecology and Evolutionary Biology, University of California, \\ Los Angeles, Los Angeles, California, United States
}

\begin{abstract}
One of the most successful avian urban invaders is the House Sparrow (Passer domesticus). Here, we examine House Sparrow numbers in the urban-agricultural landscape of three cities, one where the sparrow is native (Barcelona) and two where it is nonnative (Los Angeles, Mexico City), comparing between five different land classes based on land-use, location relative to urban center, and urbanization intensity. We estimated sparrow densities using distance-sampling corrected procedures and compared sparrow numbers between the three cities and between the land classes within each city. This two-year survey showed the highest density of sparrows occurring in Mexico City and the lowest in Los Angeles. In both cities where the sparrow is nonnative, we recorded the greatest abundances in highly urbanized areas. In Barcelona, where the sparrow is native, abundances did not differ among land classes. We also related sparrow numbers to specific environmental variables, describing vegetation structure, urban infrastructure, and human activity, using classification and regression trees. We found several variables related to differences in House Sparrow abundances among the three cities. For Los Angeles and Mexico City, the most important variables explaining House Sparrow numbers were urban infrastructure (i.e., maximum building height, high urbanization) and/or human activity (i.e., pedestrians), all of which related positively with sparrow abundance. For Barcelona, sparrow numbers showed both positive and negative relationships with vegetation (i.e., tree abundance, maximum tree height, maximum herbaceous plant height) and human-related variables (i.e., cars, pedestrians). Although the scope of this study is geographically limited to three cities, our results suggest that House Sparrow numbers between cities and land classes areas vary considerably, and are likely determined by a complex array of variables. Our study provides some insight to the growth and decline of House Sparrow populations in their nonnative and native ranges, respectively.
\end{abstract}

\section{Alerte aux envahisseurs: Densités de moineaux domestiques au long de trois paysages agrico-urbains}

RÉSUMÉ. Un des envahisseurs aviaires ayant le plus de succès est le Moineau Domestique (Passer domesticus). Ici, nous examinons les densités dans les zones agrico-urbaines de trois villes, une où le moineau est natif (Barcelone) et deux où l'espèce est considérée envahissante (Los Angeles, Mexico), en comparant entre cinq classifications terrestres établit selon l'utilisation du territoire, localisation relative au centre urbain, et l'intensité d'urbanisation. Nous avons estimé les densités de moineaux en utilisant la méthode d'échantillonnage selon la distance corrigée et avons comparé le nombre de moineau entre les trois villes, ainsi qu'entre les classifications terrestres dans chaque ville. Cet échantillonnage de deux ans a démontré la plus grande densité à Mexico et la plus basse à Los Angeles. Chez les deux villes où le moineau est considéré comme envahissant, les densités les plus élevées furent enregistrées dans les zones très urbanisées. À Barcelone, où le moineau est natif, les abondances ne démontrent pas de différences entre les classifications terrestres. Nous avons aussi relié le nombre de moineau à des variables environnementales spécifiques, décrivant la structure de la végétation, les infrastructures urbaines, les activités humaines, en utilisant les méthodes de classification et régression arborescentes. Nous avons trouvé plusieurs variables reliées à des différences chez le Moineau Domestique parmi les trois villes. À Los Angeles et Mexico, les variables les plus importantes expliquant les densités du Moineau Domestique sont les infrastructures urbaines (c.-à-d., hauteur maximum de l'édifice, haut degré d'urbanisation) et/ou l'activité humaine (c.-à-d., piétons), tous démontrent un lien positif avec l'abondance de moineaux. En ce qui concerne Barcelone, des liens positives et négatives sont associés avec la végétation (c.-à-d., abondance d'arbre, hauteur maximum d'arbre, hauteur maximum des plantes herbacées) ainsi que les variables anthropogéniques (c.-à-d., voitures, piétons). Bien que la portée de cette étude soit limitée géographiquement à trois villes, nos résultats suggèrent une considérable variation du nombre de Moineaux Domestiques entre les villes, ainsi que les classifications terrestres, et est probablement déterminée par un éventail complexe de variables. Notre étude apporte un aperçu de la croissance et du déclin des populations de Moineaux Domestiques dans leurs aires de répartition respectives, qu'elle soient invasives ou naturelles. .

Key Words: Exotic; nonnative; Passer domesticus; urban ecology

Address of Correspondent: Pamela J Yeh, Department of Ecology and Evolutionary Biology, University of California, Los Angeles, Charles E. Young Drive South, Los Angeles, California, 90095 United States, pamelayeh@ucla.edu 


\section{INTRODUCTION}

Urbanization is a process that drastically alters pre-existing systems and concentrates significant amounts of resources to satisfy the needs of modern life (McDonnell and MacGregorFors 2016, Seto and Ramankutty 2016). This generates enormous environmental impacts at various geographic scales, ranging from the local to the global (Seto and Ramankutty 2016). In fact, urbanization is related to a broad range of long-term cascading ecological impacts, especially for native flora and fauna (Czech et al. 2000, Berkowitz et al. 2003, Jetz et al. 2007, Grimm et al. 2008, Pickett et al. 2008, Aronson et al. 2014, Seto and Ramankutty 2016). This can importantly affect the ecology of an entire geographic region, and, as a result, threaten native species (Emlen 1974, Beissinger and Osborne 1982, Czech et al. 2000, Van Rensburg et al. 2009, Maxwell et al. 2016). As urbanization poses novel pressures to biodiversity, some species are able to adapt, and even thrive, within urban centers, while those unable to do so decline in number (Chace and Walsh 2006, Evans et al. 2009, Fischer et al. 2015). In particular, several bird species have been shown to successfully exploit areas of human development, to the degree that they have established populations beyond their native geographic ranges (Blair 1996, Shochat 2004, Kark et al. 2007, Blackburn et al. 2009).

The House Sparrow (Passer domesticus) has been introduced anthropogenically worldwide, making it one of the most prolific and successful introduced bird species in the world (Anderson 2006, Lowther and Cink 2006, Aronson et al. 2014). Native to Eurasia, the House Sparrow has been dominant and successful at exploiting urban areas of North America, often repelling potential competitor avifauna (Gavareski 1976, Gowaty 1984, Clergeau et al. 1998, White et al. 2005, MacGregor-Fors et al. 2010). The success of the House Sparrow as an urban exploiter species in North America has been mainly attributed to four natural history traits: (1) it is a dietary generalist that feeds on grains, insects, fruits, and even human litter (Gavett and Wakeley 1986, Kimball 1997); (2) it has colonial-communal nesting strategies that allow for rapid proliferation upon invading new areas (Kalinoski 1975, McGillivray 1980, Gowaty 1984); (3) it can effectively expand its ranges throughout human-altered landscapes (Kark et al. 2007); and (4) it is a territorial species that actively destroys the nests of other species (McGillivray 1980, Gowaty 1984, Kimball 1997).

Since its introduction in the northeastern United States in the 1800s, the House Sparrow has steadily expanded its range across human-disturbed landscapes, establishing large populations in urban centers (Johnston and Selander 1973, Baughman 2003, Lowther and Cink 2006). Although records of its arrival to Mexico are sparse, it presumably arrived in Mexico City by the 1930s (Wagner 1959). We have no information about its presence in Central America until the 1970s (Davis 1972). Although potential habitat for the species in Mexico only excludes the Southern Baja Peninsula, northwestern Mexico, and Yucatan Peninsula (Navarro and Peterson 2007), its presence is closely associated with that of human development, especially from within the heavily developed urban centers out to isolated farmlands. They are rarely found in undisturbed areas (SummersSmith et al. 2017). In its native Eurasian range, House Sparrow populations have experienced considerable declines as a result of a suite of complex anthropogenic factors (Robinson et al. 2005, Brichetti et al. 2007, Ferrer et al. 2013, PECBMS 2013, 2016).

Previous studies have investigated House Sparrow success in relation to specific habitat features. Recent studies performed in Mexican cities, i.e., Mexico City, Morelia, that examined the effects of built cover and building height showed that avian communities in areas invaded by the sparrows had lower species richness in comparison to those of noninvaded areas (Ortega-Álvarez and MacGregor-Fors 2009). This indicates that House Sparrow success in invading nonnative areas, mainly through its synergistic interactions with human activity, is closely related to changes in the diversity, composition, and structure of native bird communities (MacGregor-Fors et al. 2010). More generally, another study found that urban residential bird communities can experience lower species richness but greater abundances, with those in commercial areas favoring generalist and urban exploiter species (Ortega-Álvarez and MacGregor-Fors 2009). Yet, the House Sparrow is comparably less abundant in other Mexican cities, e.g., Xalapa (Escobar-Ibáñez and MacGregor-Fors 2016). Also, House Sparrow abundances have been found to vary between the four urban land-uses of Mexico City, with the highest numbers recorded in residential-commercial areas and the lowest in green areas (Ortega-Álvarez and MacGregor-Fors 2011). This study showed that the variables determining House Sparrow numbers vary among urban land-uses, with some variables consistently positively related, e.g., number of passing pedestrians or building height, and others consistently negatively related, e.g., tree density and cover.

Similar patterns of habitat relationships have also been reported in this species' native European distribution (Mason 2006, Chamberlain et al. 2007, Tratalos et al. 2007, Murgui 2009, Murgui and Macías 2010, García-Rodríguez 2011, Šálek et al. 2015), where variables associated with vegetation, but not specifically with urbanization, have been shown to drive their numbers. The declines of native House Sparrow populations have been recorded in both urban and agricultural areas, although the processes are seemingly different. For instance, its populations have experienced considerable declines since the replacement of horses by cars in the 1920s, followed by nonurban population declines associated with the reduced availability of both grain and invertebrates due to the industrialization of farmland practices, e.g., heavier use of pesticides and herbicides, reduced grain spillage, improved grain storage, from the 1980s onward (Summers-Smith 2003). The renewed decline of its urban populations since the 1990s has been much more complex and highly variable with the reduced number of shrubs and nesting sites, increased pesticides use in greenspaces, and increased concentration of lower socioeconomic status areas all being related to lower sparrow numbers (Summers-Smith 2003, Balmori and Hallberg 2007, Shaw et al. 2008, Murgui and Macías 2010, García-Rodríguez 2011). However, it is unclear which of these reasons are directly causing the decline (De Laet and Summers-Smith 2007).

The success of the House Sparrow in North America has been extensively studied in terms of its multiple introductions and subsequent differentiation among populations (Johnston and Selander 1964, Brown and Wilson 1975, Baughman 2003, Lowther and Cink 2006). Yet, how the numbers of this sparrow might differ along urban-agricultural landscapes where it is native and 
Fig. 1. Map of the three studied urban-agricultural landscapes. Gray polygons of insets correspond to the urban agglomerations.

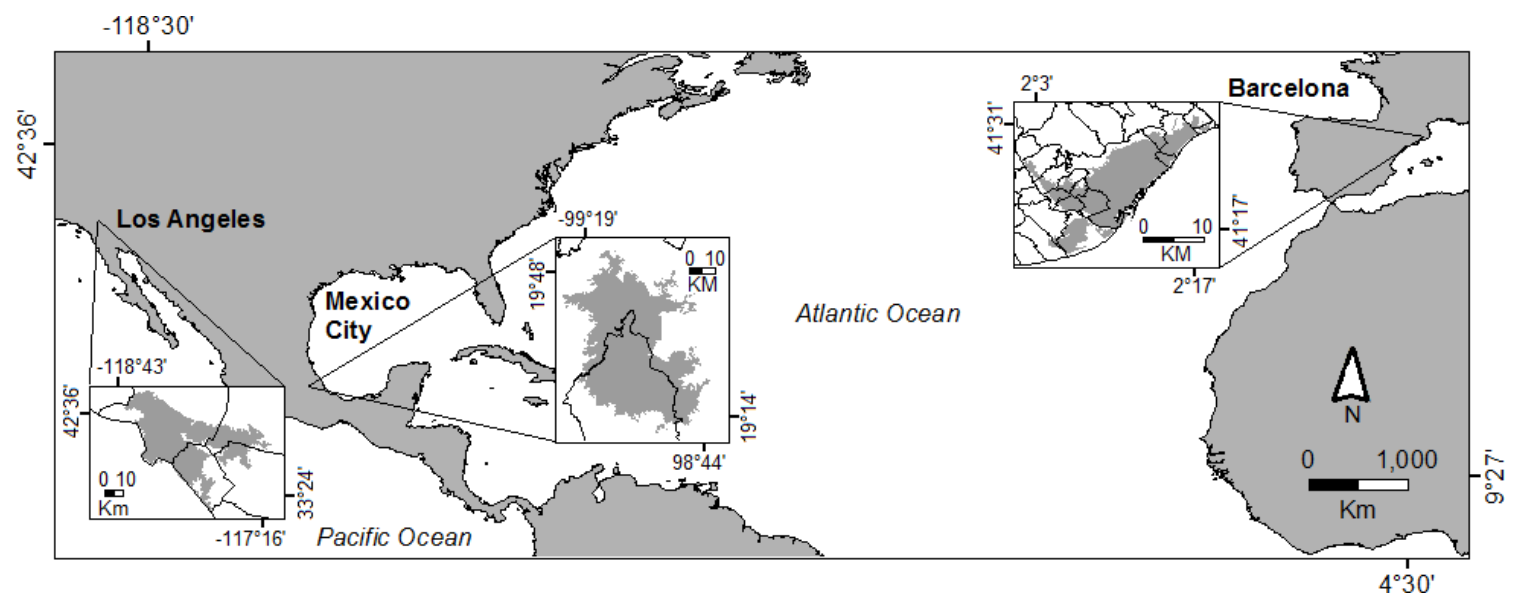

nonnative is not well understood. By setting up our study in a comparative framework that includes different urbanagricultural land classes, based on land-use, location relative to urban centers, and urbanization intensity, we provide insight to the paradox of the growth and decline of House Sparrows in their nonnative and native ranges, respectively. Moreover, there is an important lack of knowledge regarding the environmental variables related to their numbers along urban-agricultural landscapes. Thus, the aim of our study is to document how the House Sparrow numbers differ in five different land classes, i.e., intra-urban high urbanization, intra-urban low urbanization, peri-urban high urbanization, peri-urban low urbanization, and agricultural, in three cities, one located within its native distribution, Barcelona; two in its North American invasion, Los Angeles, Mexico City. Specifically, we ask the following: (1) how do House Sparrow densities differ between three cities, (2) how do their abundances differ among land classes, defined by geographic location and urbanization intensity, and (3) which variables, e.g., vegetation structure, urban infrastructure, and/or human activity, are related to House Sparrow numbers across the studied urban-agricultural landscapes?

\section{METHODS}

\section{Study areas}

This study was conducted in three urban-agricultural landscapes: Los Angeles (California, United States), Mexico City (Mexico), and Barcelona (Catalonia, Spain; Fig. 1, Table 1). We worked in urban-agricultural landscapes, including urban agglomerations rather than governmentally delimited cities, to assess House Sparrow abundances. Focusing on governmentally delimited urban boundaries did not allow us to consider House Sparrow abundance variations when comparing urban cores and periurban areas.

\section{Focal land classes within urban-agricultural landscapes}

We established our study sites in urban, e.g., residential or commercial, and agricultural land-uses, because the House Sparrow's native and nonnative distributions are generally limited to these types of areas (Cramp 1998, Anderson 2006, Lowther and Cink 2006, Murgui 2009). Specifically, for each urban area, we assessed House Sparrow numbers between five land classes: (1) intra-urban high urbanization; (2) intra-urban low urbanization; (3) peri-urban high urbanization; (4) peri-urban low urbanization; and (5) agricultural. We categorized these land classes based on three dichotomous environmental conditions that have been shown to drive bird distributions in urban areas: land-use, i.e., urban, agricultural; location relative to urban centers, i.e., intra-urban, peri-urban (López 2010, Puga-Caballero et al. 2014); and urbanization intensity, i.e., low, high urbanization (Chace and Walsh 2006, Evans et al. 2009).

We selected sites within each land class using high quality satellite imagery based on land-use, location relative to urban centers, and urbanization intensity variables. We established a $\sim 50 \%$ built cover threshold to differentiate between sites with low and high urbanization, i.e., $0-50 \%=$ low urbanization; $51-100 \%=$ high urbanization. To distinguish between intra- and peri-urban areas, we used methods to delineate the limit of the peri-urban area of an urban agglomeration (MacGregor-Fors 2010). Briefly, this method calculates the representative area in which the urban core intermingles with adjacent nonurban systems, representing an ecologically meaningful ecotone for birds (Puga-Caballero et al. 2014). Regarding agricultural sites, we selected them in croplands with few built elements $(0-30 \%$ built cover) along the city outskirts. We verified that our sites matched the correct parameters of the land class by manually quantifying built cover, i.e., all hard and relatively impervious surfaces, including buildings and paved streets, on the satellite imagery.

\section{Point-count surveys}

We surveyed House Sparrows over a two-year period, for the winter seasons (December-January) of 2012-2013 and 20132014, and the breeding seasons (May-June) of 2013 and 2014. We used limited radius point-counts, at which we recorded all House Sparrows seen or heard within a 50-m radius in a five-min period (following Ralph et al. 1993), from 07:00 to 11:00. In order to calculate distance-sampling corrected densities, we measured the radial distances from each recorded sparrow to the observer using laser rangefinders (Bushnell Yardage Pro Sport 450, 
Table 1. Geographical and population traits for the three studied urban-agricultural landscapes.

\begin{tabular}{|c|c|c|c|}
\hline & $\begin{array}{c}\text { Los Angeles } \\
\text { (California, USA) }\end{array}$ & $\begin{array}{c}\text { Mexico City } \\
\text { (Mexico) }\end{array}$ & $\begin{array}{c}\text { Barcelona } \\
\text { (Catalonia, Spain) }\end{array}$ \\
\hline Location (urban center) & $34^{\circ} 3^{\prime} 4^{\prime \prime} \mathrm{N}, 118^{\circ} 14^{\prime} 37^{\prime \prime} \mathrm{W}$ & $19^{\circ} 25^{\prime} 56^{\prime \prime} \mathrm{N}, 99^{\circ} 7^{\prime} 59^{\prime \prime} \mathrm{W}$ & $41^{\circ} 23^{\prime} 30^{\prime \prime} \mathrm{N}, 2^{\circ} 10^{\prime} 25^{\prime \prime} \mathrm{E}$ \\
\hline Average elevation ( $\mathrm{m}$ asl) & 93 & 2250 & 12 \\
\hline Territory $\left(\mathrm{km}^{2}\right)^{\dagger}$ & 5889 & 1789 & 207 \\
\hline Population (million) & 12.3 & 20.8 & 5.2 \\
\hline
\end{tabular}

Overland Park, KS). We established our point-count locations at a minimum separation distance of $200 \mathrm{~m}$ to avoid issues of pseudoreplication (Ralph et al. 1993, 1995). We performed 10 point-counts within one- or two-morning periods, depending on weather conditions and logistical reasons, for each land class for the three surveyed cities. This resulted in a total of 150 pointcounts per survey season in all three cities. Each site was repeated once per season, for a total of 600 point-count repetitions.

\section{Environmental variables}

In order to assess which environmental variables were related to House Sparrow numbers in the three surveyed cities, we reviewed previous studies relating the presence and abundances of urbanexploiter species to environmental variables (e.g., Kark et al. 2007, Evans et al. 2009, Murgui and Macías 2010, Ortega-Álvarez and MacGregor-Fors 2009, 2011). We identified 12 specific variables that describe vegetation structure, urban infrastructure, and human activity, which we sampled within the 50-m radius area at which we surveyed the sparrows: (1) tree cover, (2) tree abundance, (3) maximum tree diameter at breast height (DBH), (4) maximum tree height, (5) shrub cover, (6) maximum herbaceous plant height, (7) number of lamp poles, (8) number of telephone and electric power poles, (9) number of telephone and electric power cables, (10) maximum building height, (11) number of passing pedestrians in five min, and (12) number of passing cars in five $\min$.

\section{Data analysis}

We estimated House Sparrow densities using the distancesampling corrected procedures in Distance 6.0 (Thomas et al. 2010). This software estimates density by calculating the detection probability of individuals (ind/ha) at increasing distances from the observer, and then by standardizing the detection rates along the concentric surveyed area (Buckland et al. 2001). Although detectability can differ among land classes, our data were not sufficient for performing distance-corrected analyses by "land class" but were sufficient for "city" and "season." With its capabilities of correcting for detection probability as well as standardizing by the surveyed area, we believe that the use of Distance is crucial for avoiding important biases in our results, assuming pooled "land class" detection probabilities. We used the key function/series expansion combination that best fitted our data for each city/season based on the Akaike Information Criterion (AIC) and coefficient of variance. To determine statistical differences between the density estimations between the three cities, we compared their $84 \%$ confidence intervals, following MacGregor-Fors and Payton (2013). Given that overlapping $95 \%$ confidence intervals fail in detecting statistical differences with an $\alpha \leq 0.05$, we used $84 \%$ confidence intervals, which have been shown to approximate overlapping confidence intervals with an $\alpha \approx 0.05$ for both symmetrical and asymmetrical intervals; for House Sparrow density estimations, confidence intervals are asymmetrical, from normal and log-normal distributions (Payton et al. 2003, MacGregor-Fors and Payton 2013). Hence, when the $84 \%$ confidence intervals for the density estimations of two groups did not overlap, we considered them to be statistically different from one another; when their confidence intervals did overlap, we considered them to not be statistically different from one another.

For comparisons between land classes within cities, we were unable to use distance-sampling corrected density estimations because of the low numbers of recorded House Sparrows in some of the land classes; in agricultural areas, sparrows were found in more sparsely distributed and tighter groups. Thus, we used the observed House Sparrows individuals/point-count, rather than density estimations, for making comparisons between land classes within cities. We performed general linearized mixed models (GLMM) of House Sparrow numbers using Poisson family and a log-link function (package lme4; Bates et al. 2016) in R (R Core Team 2017). We used House Sparrow individuals/point-count as the response variable and the land class, season, and year as predictor variables. We selected the most parsimonious model based on the Akaike information criterion (AIC). We considered point-counts as a random variable and used a dummy data variable to control for model overdispersion. We used the best model to perform pairwise Tukey comparisons for establishing statistical differences in the abundance of House Sparrows per point-count between land classes within the urban-agricultural landscapes.

Finally, to assess the relationships between House Sparrow abundances per point-count and environmental variables at each city, we performed two analyses. Given that exploratory analyses allowed us to identify potential nonlinear relationships between our independent variables and House Sparrow numbers in the three studied cities, we first performed a generalized additive mixed model (GAMM) considering "city" as a random factor. GAMMs are similar to GLMs in having different error structures and link functions, but the shape of relationships is not specified by explicit functional forms; instead, nonparametric "smoothers" to describe the specified nonlinear relationship, as well as random (nonfixed) factors/effects (Crawley 2013). Based on the set of significantly related variables identified through the GAMM, we performed classification and regression tree (CART) analyses using R ( R Core Team 2017) for the three studied cities, 
considering "city," "land class," and "season" as independent variables, besides the other eight independent variables identified by the GAMM. This exploratory general CART showed "land class" to be, hierarchically, the most important variable explaining variance in House Sparrow numbers in the three cities, followed by "city," passing pedestrians, maximum building height, passing cars, maximum tree height, maximum herbaceous plant height, tree abundance, and poles. Thus, we performed three additional CARTs, one per city, considering the eight independent variables identified by the GAMM, as well as "land class." We used CARTs because they allow the interpretation of datasets where complex nonlinear relationships occur between the set of response and predictor variables (De'ath and Fabricius 2000). These trees are analogous to multiple regression models, specifically to those using the forward selection of predictor variables (Crawley 2007, 2013). By using binary recursive partitioning to identify the successive critical threshold values for a set of predictor variables, CARTs split the dataset of the response variable in a dichotomous and hierarchical manner; as a result, the rank order of only one numeric predictor variable is identified at each split of the tree, showing not only relationships, but also scenarios under which independent variables can relate differently to the dependent one (Palomino and Carrascal 2007). We used the function "rpart" for R (Therneau et al. 2015, R Core Team 2017) because it carries out analysis of variance with the two-level variables associated with each split, which makes it more suitable for anticipating the results of simplified models compared to functions like "tree" (Crawley 2013). This procedure is well suited for assessing relationships between a dependent variable (in this case, House Sparrow abundance per point-count) and multiple independent variables, which can be a mix of continuous and categorical variables (in this case, the 12 environmental variables sampled within the $50-\mathrm{m}$ radius area of where sparrows were surveyed) even if they are highly correlated (Andersen et al. 2000, Jackson and Bartolome 2002).

\section{RESULTS}

After quantifying built cover using the satellite imagery for all survey sites, we confirmed that our defined land classes within the urban-agricultural landscapes are unique, based on land-uses, location relative to urban centers, and urbanization intensity (Table 2). Built cover in the surveyed sites was very low in agricultural fields (average 5.7\% \pm SE 1.6), with all sites showing values $<30 \%$. For low urbanization sites, average built cover was $13.43 \%$ ( \pm SE 2.1$)$; all values, except for one site in Los Angeles, i.e., intra-urban low urbanization, $55.1 \%$ built cover, had $<50 \%$ built cover. For high urbanization sites, average built cover was $77.3 \%$ ( \pm SE 2.1 ), with only two peri-urban sites having $<50 \%$ built cover in Barcelona, i.e., $41.9 \%$ and $45.9 \%$ built cover.

House Sparrow densities differed significantly between the three surveyed cities (Fig. 2). Within each city, we found no difference between seasons, with the exception of the 2014 breeding season in Mexico City. The number of House Sparrows per hectare in Mexico City ( $84 \%$ CI range for both seasons in both years: 9.5-33.3 sparrows/ha) was significantly higher when compared to the numbers estimated for Los Angeles (84\% CI range for both seasons in both years: 0.4-3.1 sparrows/ha) and Barcelona (84\% CI range for both seasons in both years: $3.2-7.1$ sparrows/ha).
We found differences in House Sparrow abundances per pointcount when comparing between land classes within both Los Angeles and Mexico City; however, no differences were found when comparing between land classes within Barcelona (Tables 3 and 4). We recorded the highest House Sparrow abundances in the intra-urban high urbanization land class within both Mexico City and Los Angeles (Fig. 3). In Mexico City, we recorded a high number of House Sparrows in the peri-urban high urbanization land class, with only a few or no individuals in the remaining land classes. Furthermore, in Mexico City we recorded no House Sparrows in agricultural areas.

Table 2. Built cover (average \pm SD) of the sites in which we surveyed House Sparrows (Passer domesticus) by city and "land class."

\begin{tabular}{lccc}
\hline \hline & Los Angeles & Mexico City & Barcelona \\
\hline Agriculture & $14.5 \pm 10.9$ & $0.7 \pm 1.5$ & $4.3 \pm 8.7$ \\
Peri-urban Low Urbanization & $12.3 \pm 16.0$ & $10.5 \pm 16.8$ & $12.3 \pm 15.9$ \\
Peri-urban High Urbanization & $66.3 \pm 9.0$ & $84.7 \pm 11.9$ & $59.7 \pm 10.1$ \\
Intra-urban Low Urbanization & $36.1 \pm 21.5$ & $4.8 \pm 7.4$ & $8.0 \pm 11.1$ \\
Intra-urban High Urbanization & $96.3 \pm 2.7$ & $68.2 \pm 9.1$ & $87.5 \pm 11.8$
\end{tabular}

Fig. 2. House Sparrow (Passer domesticus) distance-sampling corrected density estimations for Los Angeles, Mexico City, and Barcelona. To compare sparrow densities between cities, we considered two groups statistically different from one another when their $84 \%$ confidence intervals did not overlap, while we considered them not statistically different from one another when their confidence intervals did overlap.

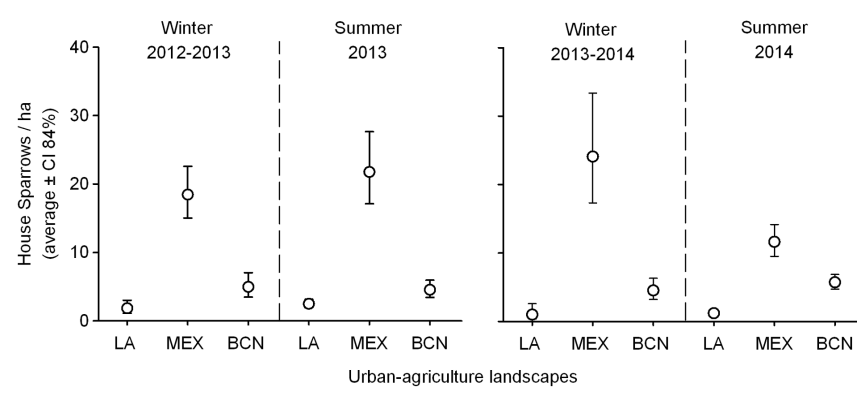

Results of the GAMM show that 8 out of the 12 assessed variables were significantly related with House Sparrow numbers, showing the importance of both "city" and "land class," as well as no effect of "season" (Table 5). Results of the CARTs for each city using the eight variables identified by the GAMM as well as "land class" show that the most important variables for explaining sparrow number differences, being the earliest splits in the trees, were maximum tree height in Barcelona, maximum building height in Los Angeles, and "land class" (separating agriculture and low urbanization from high urbanization sites) in Mexico City (Fig. 4). CARTs show that both vegetation and human-related variables explain shifts in House Sparrow numbers in Barcelona, while high urbanization scenarios, as indicated by results of the GLMM (Tables 3 and 4), show a positive relationship with their 
Table 3. General linearized mixed models for House Sparrow (Passer domesticus) abundances in the three studied urban-agricultural landscapes. The most parsimonious model was selected based on the lowest AIC score.

\begin{tabular}{|c|c|c|c|c|c|}
\hline \multirow{2}{*}{$\begin{array}{l}\text { Urban-agricultural } \\
\text { landscape }\end{array}$} & \multicolumn{5}{|c|}{ Model parameters and statistics } \\
\hline & & Estimate & Std. Error & z-value & $\mathrm{P}$ \\
\hline Los Angeles & $\begin{array}{l}\text { Intercept } \\
\text { Intra-urban High Urbanization } \\
\text { Intra-urban Low Urbanization } \\
\text { Peri-urban High Urbanization } \\
\text { Peri-urban Low Urbanization } \\
\text { Season } \\
\text { Year } \\
\text { AIC }{ }^{\dagger} \text { : M1 }=675.84 ; \mathrm{M} 2=645.66 ; \mathrm{M} 3=647.67^{\ddagger} \\
\text { Variance: Point-count }(\text { random })=3.16 ; \text { Dummy }=0.00\end{array}$ & $\begin{array}{c}1.49 \\
1.74 \\
-1.25 \\
-17.74 \\
-1.4 \\
-13.22 \\
-0.81\end{array}$ & $\begin{array}{c}0.56 \\
0.59 \\
0.88 \\
3036.49 \\
0.4 \\
318.22 \\
0.53\end{array}$ & $\begin{array}{c}-2.65 \\
2.93 \\
-1.42 \\
-0.006 \\
-3.49 \\
-0.042 \\
-1.52\end{array}$ & $\begin{array}{c}\mathrm{p}<0.01 \\
\mathrm{p}<0.01 \\
0.15 \\
0.15 \\
\mathrm{p}<0.001 \\
0.97 \\
0.13\end{array}$ \\
\hline Barcelona & $\begin{array}{l}\text { Intercept } \\
\text { Intra-urban High Urbanization } \\
\text { Intra-urban Low Urbanization } \\
\text { Peri-urban High Urbanization } \\
\text { Peri-urban Low Urbanization } \\
\text { Season } \\
\text { Year } \\
\text { Season } \times \text { Year } \\
\text { AIC }: \text { M1 }=874.20 ; \text { M2 }=745.40 ; \text { M3 }=737.52^{\ddagger} \\
\text { Variance: Point-count }(\text { random })=0.77 ; \text { Dummy }=0.74\end{array}$ & $\begin{array}{c}\text { Estimate } \\
0.33 \\
0.55 \\
0.23 \\
0.83 \\
-0.69 \\
-1.92 \\
0.03 \\
1.23\end{array}$ & $\begin{array}{c}\text { Std. Error } \\
0.38 \\
0.49 \\
0.49 \\
0.48 \\
0.52 \\
0.33 \\
0.23 \\
0.4\end{array}$ & $\begin{array}{c}\mathrm{z} \text {-value } \\
0.88 \\
1.12 \\
0.47 \\
1.72 \\
-1.32 \\
-5.88 \\
0.12 \\
3.08\end{array}$ & $\begin{array}{c}\mathrm{P} \\
0.38 \\
0.26 \\
0.64 \\
0.09 \\
0.19 \\
\mathrm{p}<0.001 \\
0.9 \\
0.002\end{array}$ \\
\hline Mexico City & $\begin{array}{l}\text { Intercept } \\
\text { Intra-urban High Urbanization } \\
\text { Intra-urban Low Urbanization } \\
\text { Peri-urban High Urbanization } \\
\text { Peri-urban Low Urbanization } \\
\text { Season } \\
\text { Year } \\
\text { AIC } \text { V }^{\dagger} \text { M }=866.28 ; \mathrm{M} 2=795.30 ; \mathrm{M} 3=796.46^{\star} \\
\text { Variance: Point-count(random })=0.34 ; \text { Dummy }=0.26\end{array}$ & $\begin{array}{c}\text { Estimate } \\
0.02 \\
0.02 \\
0.02 \\
0.02 \\
-0.75 \\
-0.13 \\
0.49\end{array}$ & $\begin{array}{c}\text { Std. Error } \\
0 \\
0 \\
0 \\
0 \\
0.42 \\
0.15 \\
0.17\end{array}$ & $\begin{array}{c}\text { z-value } \\
0 \\
0 \\
0 \\
0 \\
-18 \\
-0.82 \\
2.93\end{array}$ & $\begin{array}{c}\mathrm{P} \\
0.99 \\
0.99 \\
0.99 \\
0.99 \\
0.07 \\
0.41 \\
\mathrm{p}<0.01\end{array}$ \\
\hline
\end{tabular}

Table 4. Pairwise Tukey comparisons for House Sparrow (Passer domesticus) abundances in the five land classes of the three studied urban-agricultural landscapes.

\begin{tabular}{|c|c|c|c|c|}
\hline & $\begin{array}{c}\text { Peri-urban Low } \\
\text { Urbanization }\end{array}$ & $\begin{array}{l}\text { Peri-urban High } \\
\text { Urbanization }\end{array}$ & $\begin{array}{c}\text { Intra-urban Low } \\
\text { Urbanization }\end{array}$ & $\begin{array}{c}\text { Intra-urban High } \\
\text { Urbanization }\end{array}$ \\
\hline \multicolumn{5}{|l|}{ Los Angeles } \\
\hline Agricultural & $\mathrm{p}<0.01$ & 1 & 0.38 & 0.6 \\
\hline Peri-urban Low Urbanization & - & $\mathrm{p}<0.01$ & 0.35 & $\mathrm{p}<0.001$ \\
\hline Peri-urban High Urbanization & - & - & 0.24 & 0.78 \\
\hline Intra-urban Low Urbanization & - & - & - & $\mathrm{p}<0.05$ \\
\hline \multicolumn{5}{|l|}{ Barcelona } \\
\hline Agricultural & 0.72 & 0.39 & 0.98 & 0.78 \\
\hline Peri-urban Low Urbanization & - & 0.06 & 0.39 & 0.13 \\
\hline Peri-urban High Urbanization & - & - & 0.73 & 0.97 \\
\hline Intra-urban Low Urbanization & - & - & - & 0.97 \\
\hline \multicolumn{5}{|l|}{ Mexico City } \\
\hline Agricultural & 0.37 & $\mathrm{p}<0.001$ & 0.97 & $\mathrm{p}<0.001$ \\
\hline Peri-urban Low Urbanization & - & $\mathrm{p}<0.001$ & $\mathrm{p}<0.001$ & $\mathrm{p}<0.001$ \\
\hline Peri-urban High Urbanization & - & - & $\mathrm{p}<0.001$ & 0.98 \\
\hline Intra-urban Low Urbanization & - & - & - & $\mathrm{p}<0.001$ \\
\hline
\end{tabular}


Fig. 3. House Sparrow (Passer domesticus) abundances per point-count recorded in the three surveyed urbanagricultural landscapes.
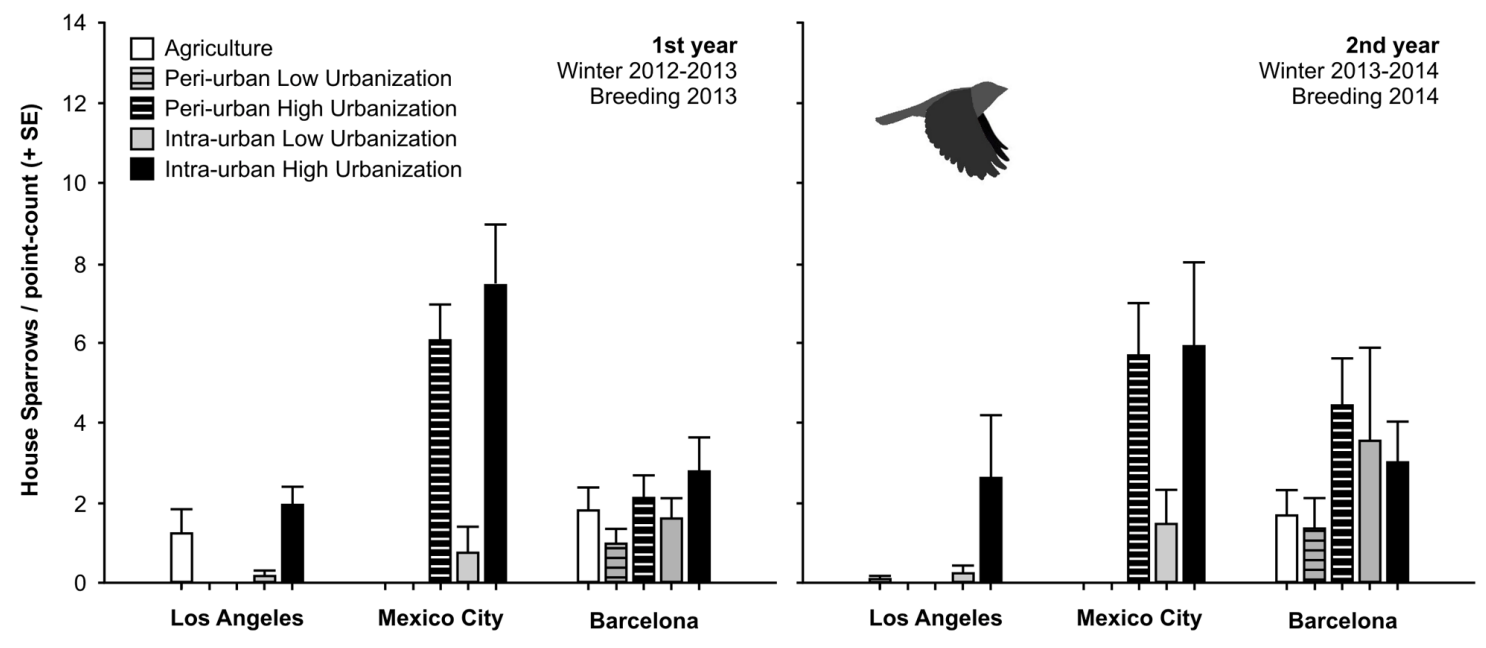

Fig. 4. Classification and regression trees (CART) show the relationships between House Sparrow (Passer domesticus) abundances per point-count and eight predictor environmental variables as well as "land class." Analysis of variance successively splits the dataset based on predictor variables that best explain the variability of the response variable (critical threshold values of each such variable are located below each tree split): subsets with mean values of the response variable corresponding to the marked threshold are placed: true on the left side and false on the right side. Given the nature of the relationships, some continuous variables may appear at multiple tree splits, even with different relationships.

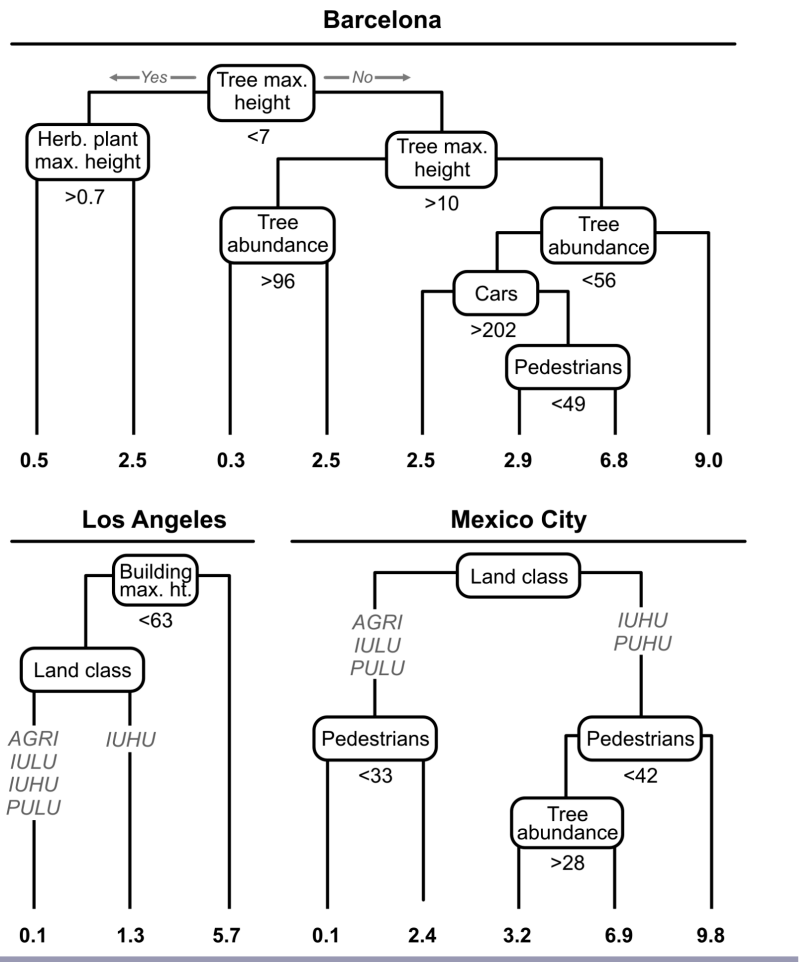

Table 5. Generalized additive mixed model for House Sparrow (Passer domesticus) abundances in the three studied urbanagricultural landscapes, considering "city" as a random factor.

\begin{tabular}{lccc}
\hline \hline Environmental variables & df & $\mathrm{F}$ & $\mathrm{P}$ \\
\hline Tree cover & 1 & 0.605 & 0.437 \\
Tree abundance & 1 & 16.21 & $<0.001$ \\
Max. tree DBH & 1 & 0.122 & 0.726 \\
Max. tree height & 2 & 4.735 & 0.009 \\
Shrub cover & 5 & 6.428 & $<0.001$ \\
Max. herbaceous plant height & 1 & 11.13 & $<0.001$ \\
Number of lamp poles & 2 & 1.272 & 0.204 \\
Number of telephone/electric power & 3 & 6.102 & 0.001 \\
poles & & & \\
Number of telephone/electric power & 1 & 0.428 & 0.513 \\
cables & & & \\
Max. building height & 5 & 3.399 & $<0.001$ \\
Number of passing pedestrians/5 min & 5 & 7.991 & $<0.001$ \\
Number of passing cars/5 min & 3 & 5.171 & 0.002 \\
& & & \\
\hline
\end{tabular}

abundances in Los Angeles and Mexico City. It is noteworthy that maximum building height and high urbanization in urban sites in Los Angeles, and high urbanization and pedestrians in Mexico City all showed positive relationships with House Sparrow abundances. Meanwhile, the only vegetation variable selected by the CARTs for these cities (i.e., tree abundance) was negatively related. In contrast, the CART for Barcelona shows a complex array of positive and negative relations with both vegetation and human-related variables.

\section{DISCUSSION}

Our study, focused on House Sparrow abundances in different land classes along three urban-agricultural landscapes, shows the highest densities in Mexico City and the lowest densities in Los Angeles. Thus, depending on specific habitats and scenarios, House Sparrow numbers can resemble those of both urban 
exploiters/dwellers (Blair 1996, Fischer et al. 2015) and urban adapters/users (Blair 1996, Fischer et al. 2015), varying between cities located outside of its native range and even between urbanagricultural land classes within those cities. This agrees with a number of other studies that have shown that sparrow numbers can vary in both their native and nonnative distribution despite their reputation for high adaptability (Johnston and Selander 1964, Johnston and Selander 1973, Kendeigh 1976, Martin et al. 2004) and exploitation of urban- and agriculture-related resources (Blair 1996, Herrando et al. 2012, Fischer et al. 2015).

We recorded a high variation in House Sparrow densities in the two cities located outside of the sparrow's native distribution. Compared to Barcelona, we recorded greater average House Sparrow densities in Mexico City ( 4 times more), while we found lower average House Sparrow densities in Los Angeles. Although there is a limited knowledge of House Sparrow density patterns along the Mexican territory, our density results are similar to those from another study conducted in Mexico City ( $\sim$ sparrows/ point-count; Ortega-Álvarez and MacGregor-Fors 2011). However, other studies have reported different House Sparrow densities in other Mexican urban areas, with higher values in Morelia ( 20 sparrows/point-count; MacGregor-Fors et al. 2010) and lower values in Xalapa ( 0.5 sparrows/point-count; J. F. Escobar-Ibáñez, personal communication). Given that the negative relationship between House Sparrow numbers and native bird species richness has only been assessed in a city where the sparrow is highly abundant, i.e., Morelia, its potential adverse effects could be density dependent, and this observed pattern may not necessarily hold across its nonnative range, although future work must be done to feasibly demonstrate this.

Regarding House Sparrow numbers in the United States, data from the North American Breeding Bird Survey (Sauer et al. 2012) show that House Sparrows in the Los Angeles area are (1) scarce in the northern parts of the urban continuum ( $\sim 1-3$ sparrows/2.5 hr of point-count surveys, at which every bird seen or heard within a 0.25 -mi radius in a 3 -min period was recorded) and (2) moderately abundant in the southern parts ( $\sim 10-30$ sparrows/2.5 $\mathrm{hr})$. This pattern in sparrow density shows that its numbers and invasive success are not homogeneous throughout urban territories and are not solely due to latitude or productivity but possibly more to specific landscape- and local-scale environmental variables (e.g., Kark et al. 2007). In such a case, this would resemble some of the patterns observed in its native areas (Murgui 2009, Šálek et al 2015).

Regarding the House Sparrow's native range, our density results for Barcelona are similar to those found by Murgui (2006) in another Spanish city (Valencia), who reported densities of $0.9-$ 8.5 sparrows/ha. Although we did not find differences in sparrow abundance between the studied land classes, other ecological patterns, such as urban metapopulation dynamics, could be driving this result (Chávez-Zichinelli et al. 2010).

When analyzing House Sparrow numbers at a finer scale, within the land classes of each urban-agricultural landscape, the highest abundance values for both Mexico City and Los Angeles were from the high urbanization land classes, for both intra- and periurban locations. This result agrees with previous studies suggesting that this sparrow can take advantage of a wide array of resources in areas where other species are not present because of the lack of suitable habitat components and the presence of urban-related hazards (Blair 1996, Kark et al. 2007). Contrasting with our observations in the agricultural sites of Barcelona, we only recorded a few individuals in the agricultural land class for Los Angeles and no individuals in the agricultural land class for Mexico City. The latter agrees with our nonsystematic observations in both areas from over the past four years: that the sparrows are often found in lower densities in these agricultural areas (I. M-F. and J. G-H. L., personal observation).

Given that 8 of the 12 environmental variables we assessed showed significant relationships with House Sparrow numbers, it is clear that vegetation structure, urban infrastructure, and human activity are related to changes in their abundance, consistent with previous studies that have reported some of these variables related with House Sparrow numbers in urban areas (Murgui 2009, MacGregor-Fors et al. 2010). Yet, the types of variables and scenarios related to variations in House Sparrow numbers differed importantly among cities. The most relevant variables in explaining variation in House Sparrow abundances in Los Angeles and Mexico City were those related to urban infrastructure, i.e., maximum building height and high urbanization, and/or human activity, i.e., passing pedestrians, all of them showing a positive relationship with House Sparrow numbers in the two cities. Furthermore, in Mexico City, tree abundance, the only vegetation variable explaining some variance of the recorded House Sparrow abundance, showed a negative relationship. In contrast, our findings for Barcelona show a complex array of scenarios under which "land class" did not play a crucial role, with no urban infrastructure variable showing an important relationship with House Sparrow numbers. Vegetation variables played the most important role, explaining variance in the sparrow's abundances, both positively and negatively. For instance, the scenario in which we recorded lower average House Sparrow numbers per point-count (0.3) involved $>96,>7 \mathrm{~m}$ trees. On the other end, the scenario in which we recorded highest average House Sparrows per point-count (9.0) has $>56,8-10 \mathrm{~m}$ trees. This further demonstrates the species' close association with highly developed and human-frequented sites, especially in nonnative areas where such features represent important foraging and nesting resources (Anderson 2006).

Although this study only considers three urban-agricultural landscapes, our results suggest that the densities and abundances of House Sparrows located outside of their native ranges are determined by environmental variables that are unique to different cities and to different land classes, locations relative to urban centers, and urbanization intensities. There are a number of further questions this study raises related to the potential effects of House Sparrow density on the native biota, as well as to its role as a driver of biodiversity in urban-agricultural landscapes. Comparative studies focused on the individual (e.g., body condition, personality), population (e.g., trends in distribution and growth, intra-specific interactions, genetics), and community approaches (e.g., diversity, interspecific interactions) related to the House Sparrow in its native and nonnative areas would provide further insight for the development of population management tools in addressing two growing concerns: (1) their recent declining native populations in Europe (Murgui 2006, De Laet and Summers-Smith 2007) and (2) the problems they pose to the local biodiversity in invaded areas (Grussing 1980). 
Responses to this article can be read online at:

http://www.ace-eco.org/issues/responses.php/1082

\begin{abstract}
Acknowledgments:
We thank our field assistants J. Oliver, R. G. de Lucas, and A. Ortega-Segalerva in Barcelona, Deanna M. Chung in Los Angeles, and Nihaib Flores Galicia in Mexico City, as well as Ina Falfán for her support in satellite image processing and analyzing. We are grateful for comments on the manuscript by Prof. D. Chamberlain. Research funds were granted by UC MEXUS-CONACYT to P. J. $Y$ and I. M-F. (CN-13-587), the Natural History Museum of Barcelona to J. Q. (PASSER-CAT-1 project), and the National Geographic Society Committee for Research and Exploration to P. J. Y.
\end{abstract}

\section{LITERATURE CITED}

Andersen, M. C., J. M. Watts, J. E. Freilich, S. R. Yool, G. I. Wakefield, J. F. McCauley, and P. B. Fahnestock. 2000. Regression-tree modeling of desert tortoise habitat in the central Mojave Desert. Ecological Applications 10:890-900. http://dx.doi. org/10.1890/1051-0761(2000)010[0890:RTMODT]2.0.CO;2

Anderson, T. R. 2006. Biology of the ubiquitous House Sparrow: from genes to populations. Oxford University Press, New York, New York, USA. http://dx.doi.org/10.1093/acprof: oso/9780195304114.001.0001

Aronson, M. F. J., F. A. La Sorte, C. H. Nilon, M. Katti, M. A. Goddard, C. A. Lepczyk, P. S. Warren, N. S. G. Williams, S. Cilliers, B. Clarkson, C. Dobbs, R. Dolan, M. Hedblom, S. Klotz, J. L. Kooijmans, I. Kühn, I. MacGregor-Fors, M. McDonnell, U. Mörtberg, P. Pyšek, S. Siebert, J. Sushinsky, P. Werner, and M. Winter. 2014. A global analysis of the impacts of urbanization on bird and plant diversity reveals key anthropogenic drivers. Proceedings of the Royal Society B: Biological Sciences 281:20133330. http://dx.doi.org/10.1098/rspb.2013.3330

Balmori, A., and O. Hallberg. 2007. The urban decline of the House Sparrow (Passer domesticus): a possible link with electromagnetic radiation. Electromagnetic Biology and Medicine 26:141-151. http://dx.doi.org/10.1080/15368370701410558

Bates, D., M. Maechler, B. Bolkner, and S. Walker. 2016. Ime4: linear mixed-effects models using Eigen and S4. R package version 1.1-1.2. R Foundation for Statistical Computing, Vienna, Austria. [online] URL: http://cran.r-project.org/package=lme4

Baughman, M. 2003. National Geographic reference atlas to the birds of North America. First edition. National Geographic, Washington, D.C., USA.

Beissinger, S. R., and D. R. Osborne. 1982. Effects of urbanization on avian community organization. Condor $84: 75-83$. http://dx. doi.org/10.2307/1367825

Berkowitz, A. R., C. H. Nilon, and K. S. Hollweg. 2003. Understanding urban ecosystems: a new frontier for science and education. Springer-Verlag, New York, New York, USA.
Blackburn, T. M., J. L. Lockwood, and P. Cassey. 2009. Avian invasions: the ecology and evolution of exotic birds. Oxford University Press, New York, New York, USA. http://dx.doi. org/10.1093/acprof:oso/9780199232543.001.0001

Blair, R. B. 1996. Land use and avian species diversity along an urban gradient. Ecological Applications 6:506-519. http://dx.doi. org/10.2307/2269387

Brichetti, P., D. Rubolini, P. Galeotti, and M. Fasola. 2007. Recent declines in urban Italian House Sparrow Passer (domesticus) italiae populations in northern Italy. Ibis 150:177-181. http://dx. doi.org/10.1111/j.1474-919x.2007.00720.x

Brown, N. S., and G. I. Wilson. 1975. A comparison of ectoparasites of the House Sparrow (Passer domesticus) from North America and Europe. American Midland Naturalist 94:154-165. http://dx.doi.org/10.2307/2424546

Buckland, S. T., D. R. Anderson, K. P. Burnham, J. L. Laake, D. L. Borchers, and L. Thomas. 2001. Introduction to distance sampling. Oxford University Press, New York, New York, USA.

Chace, J. F., and J. J. Walsh. 2006. Urban effects on native avifauna: a review. Landscape and Urban Planning 74:46-69. http://dx.doi.org/10.1016/j.landurbplan.2004.08.007

Chamberlain, D. E., M. P. Toms, R. Cleary-McHarg, and A. N. Banks. 2007. House Sparrow (Passer domesticus) habitat use in urbanized landscapes. Journal of Ornithology 148:453-462. http:// dx.doi.org/10.1007/s10336-007-0165-x

Chávez-Zichinelli, C. A., I. MacGregor-Fors, P. T. Rohana, R. Valdéz, M. C. Romano, and J. E. Schondube. 2010. Stress responses of the House Sparrow (Passer domesticus) to different urban land uses. Landscape and Urban Planning 98:183-189. https://doi.org/10.1016/j.landurbplan.2010.08.001

Clergeau, P., J. P. L. Savard, G. Mennechez, and G. Falardeau. 1998. Bird abundance and diversity along an urban-rural gradient: a comparative study between two cities on different continents. Condor 100:413-425. http://dx.doi.org/10.2307/1369707

Cramp, S. 1998. The complete birds of the Western Palearctic on $C D-R O M$. Oxford University Press, New York, New York, USA.

Crawley, M. J. 2007. The R book. First edition. John Wiley \& Sons, Chichester, UK. http://dx.doi.org/10.1002/9780470515075

Crawley, M. J. 2013. The $R$ book. Second edition. John Wiley \& Sons, Chichester, UK.

Czech, B., P. R. Krausman, and P. K. Devers. 2000. Economic associations among causes of species endangerment in the United States. BioScience 50:593-601. http://dx.doi.org/10.1641/0006-3568 (2000)050[0593:eaacos]2.0.co;2

Davis, I. 1972. A field guide to the birds of Mexico and Central America. University of Texas Press, Austin, Texas, USA.

De'ath, G., and K. E. Fabricius. 2000. Classification and regression trees: a powerful yet simple technique for ecological data analysis. Ecology 81:3178-3192. http://dx.doi.org/10.2307/177409

De Laet, J., and J. D. Summers-Smith. 2007. The status of the urban House Sparrow Passer domesticus in north-western 
Avian Conservation and Ecology 12(2): 11

Europe: a review. Journal of Ornithology 148:S275-S278. http:// dx.doi.org/10.1007/s10336-007-0154-0

Emlen, J. T. 1974. Urban bird community in Tucson, Arizona: derivation, structure, regulation. Condor 76:184-197. http://dx. doi.org/10.2307/1366729

Escobar-Ibáñez, J. F., and I. MacGregor-Fors. 2016. Peeking into the past to plan the future: assessing bird species richness in a neotropical city. Urban Ecosystems 19:657-667. http://dx.doi. org/10.1007/s11252-015-0517-X

Evans, K. L., S. E. Newson, and K. J. Gaston. 2009. Habitat influences on urban avian assemblages. Ibis 151:19-39. http://dx. doi.org/10.1111/j.1474-919x.2008.00898.x

Ferrer, X., S. Herrando, and M. Anton. 2013. Informe del seguiment d'ocells a la ciutat de Barcelona 2012. Universitat de Barcelona, Barcelona, Catalonia, Spain.

Fischer, J. D., S. C. Schneider, A. A. Ahlers, and J. R. Miller. 2015. Categorizing wildlife responses to urbanization and conservation implications of terminology. Conservation Biology 29:1246-1248. http://dx.doi.org/10.1111/cobi.12451

García-Rodríguez, P. 2011. The House Sparrow (Passer domesticus) in Barcelona: factors affecting the abundance of a species in decline. Thesis. Universitat Autònoma de Barcelona, Barcelona, Catalonia, Spain.

Gavareski, C. A. 1976. Relation of park size and vegetation to urban bird populations in Seattle, Washington. Condor 78:375-382. http://dx.doi.org/10.2307/1367699

Gavett, A. P., and J. S. Wakeley. 1986. Diets of House Sparrows in urban and rural habitats. Wilson Bulletin 98:137-144.

Gowaty, P. A. 1984. House Sparrows kill Eastern Bluebirds. Journal of Field Ornithology 55:378-380.

Grimm, N. B., S. H. Faeth, N. E. Golubiewski, C. L. Redman, J. Wu, X. Bai, J. M. Briggs. 2008. Global change and the ecology of cities. Science 319:756-760. http://dx.doi.org/10.1126/science.1150195

Grussing, D. 1980. How to control House Sparrows. Roseville Publishing House, Roseville, Minnesota, USA.

Herrando, S., A. Weiserbs, J. Quesada, X. Ferrer, J.-Y. Paquet. 2012. Development of urban bird indicators using data from monitoring schemes in two large European cities. Animal Biodiversity and Conservation 35:141-150.

Jackson, R. D., and J. W. Bartolome. 2002. A state-transition approach to understanding nonequilibrium plant community dynamics in Californian grasslands. Plant Ecology 162:49-65. http://dx.doi.org/10.1023/A:1020363603900

Jetz, W., D. S. Wilcove, and A. P. Dobson. 2007. Projected impacts of climate and land-use change on the global diversity of birds. PLoS Biology 5:e157. http://dx.doi.org/10.1371/journal.pbio.0050157

Johnston, R. F., and R. K. Selander. 1964. House Sparrows: rapid evolution of races in North America. Science 144:548-550. http:// dx.doi.org/10.1007/978-0-387-73412-5_19

Johnston, R. F., and R. K. Selander. 1973. Evolution in the House Sparrow. III. Variation in size and sexual dimorphism in Europe and North and South America. American Naturalist 107:373-390. http://dx.doi.org/10.1086/282841

Kalinoski, R. 1975. Intra- and interspecific aggression in House Finches and House Sparrows. Condor 77:375-384. http://dx.doi. org/10.2307/1366086

Kark, S., A. Iwaniuk, A. Schalimtzek, and E. Banker. 2007. Living in the city: can anyone become an 'urban exploiter'? Journal of Biogeography 34:638-651. http://dx.doi.org/10.1111/

j.1365-2699.2006.01638.x

Kendeigh, S. C. 1976. Latitudinal trends in the metabolic adjustments of the House Sparrow. Ecology 57:509-519. http:// dx.doi.org/10.2307/1936435

Kimball, R. T. 1997. Male morphology and nest-site quality in House Sparrows. Wilson Bulletin 109:711-719.

López, S. 2010. Efectos de la urbanización sobre las comunidades de aves y lepidópteros de la ciudad de Morelia. B.Sc. Thesis. Universidad Michoacana de San Nicolás de Hidalgo, Morelia, Michoacán, Mexico.

Lowther, P. E., and C. L. Cink. 2006. House Sparrow (Passer domesticus). In P. G. Rodewald, editor. The birds of North America online. Cornell Lab of Ornithology, Ithaca, New York, USA. http://dx.doi.org/10.2173/bna.12

MacGregor-Fors, I. 2010. How to measure the urban-wildland ecotone: redefining the 'peri-urban' areas. Ecological Research 25:883-887. http://dx.doi.org/10.1007/s11284-010-0717-z

MacGregor-Fors, I., L. Morales-Perez, J. Quesada, and J. E. Schondube. 2010. Relationship between the presence of House Sparrows (Passer domesticus) and Neotropical bird community structure and diversity. Biological Invasions 12:87-96. http://dx. doi.org/10.1007/s10530-009-9432-5

MacGregor-Fors, I., and M. E. Payton. 2013. Contrasting diversity values: statistical inferences based on overlapping confidence intervals. PLOS ONE 8:e56794. http://dx.doi. org/10.1371/journal.pone.0056794

Martin, L. B., M. Pless, J. Svoboda, and M. Wikelski. 2004. Immune activity in temperate and tropical House Sparrows: a common-garden experiment. Ecology 85:2323-2331. http://dx. doi.org/10.1890/03-0365

Mason, C. F. 2006. Avian species richness and numbers in the built environment: can new housing developments be good for birds? Pages 25-38 in D. L. Hawksworth and A. T. Bull, editors. Human exploitation and biodiversity conservation. Springer, Dordrecht, The Netherlands. http://dx.doi.org/10.1007/978-1-4020-5283-5_3

Maxwell, S. L., R. A. Fuller, T. M. Brooks, and J. E. M. Watson. 2016. Biodiversity: the ravages of guns, nets and bulldozers. Nature 536:143-145. http://dx.doi.org/10.1038/536143a

McDonnell, M. J., and I. MacGregor-Fors. 2016. The ecological future of cities. Science 352:936-938. http://dx.doi.org/10.1126/ science.aaf 3630

McGillivray, W. B. 1980. Communal nesting in the House Sparrow. Journal of Field Ornithology 51:371-372. 
Murgui, E. 2006. Influencia de la estructura del paisaje a diferentes escalas espaciales sobre las comunidades y poblaciones de aves urbanas. Dissertation. Universidad de València, València, València, Spain.

Murgui, E. 2009. Seasonal patterns of habitat selection of the House Sparrow Passer domesticus in the urban landscape of Valencia (Spain). Journal of Ornithology 150:85-94. http://dx.doi. org/10.1007/s10336-008-0320-Z

Murgui, E., and A. Macías. 2010. Changes in the House Sparrow (Passer domesticus) population in Valencia (Spain) from 1998 to 2008. Bird Study 57:281-288. http://dx.doi.org/10.1080/00063651003716762

Navarro, A. G., and A. T. Peterson. 2007. Passer domesticus (gorrión casero) residencia permanente. Comisión Nacional para el Conocimiento y Uso de la Biodiversidad, Ciudad de México, Mexico. [online] URL: http://www.conabio.gob.mx/informacion/ gis/?vns=gis_root/biodiv/distpot/dpaves/dpavpass/passe_domegw

Ortega-Álvarez, R., and I. MacGregor-Fors. 2009. Living in the big city: effects of urban land-use on bird community structure, diversity, and composition. Landscape and Urban Planning 90:189-195. http://dx.doi.org/10.1016/j.landurbplan.2008.11.003

Ortega-Álvarez, R., and I. MacGregor-Fors. 2011. Conociendo al gorrión casero: variación en las abundancias de Passer domesticus en diferentes tipos de uso de suelo de la Ciudad de México. El canto del Centzontle 2:15-28.

Palomino, D., and L. M. Carrascal. 2007. Threshold distances to nearby cities and roads influence the bird community of a mosaic landscape. Biological Conservation 140:100-109. http://dx.doi. org/10.1016/j.biocon.2007.07.029

Pan-European Common Bird Monitoring Scheme (PECBMS). 2013. Trends of common birds in Europe, 2013 update. European Bird Census Council, Beek-Ubbergen, Gelderland, The Netherlands. [online] URL: http://www.ebcc.info/index.php? ID $=509$

Pan-European Common Bird Monitoring Scheme (PECBMS). 2016. Trends of common birds in Europe, 2016 update. European Bird Census Council, Beek-Ubbergen, Gelderland, The Netherlands. [online] URL: http://www.ebcc.info/index.php? $\mathrm{ID}=612$

Payton, M. E., M. H. Greenstone, and N. Schenker. 2003. Overlapping confidence intervals or standard error intervals: what do they mean in terms of statistical significance? Journal of Insect Science 3(34):1-6. http://dx.doi.org/10.1673/031.003.3401

Pickett, S. T. A., M. L. Cadenasso, J. M. Grove, P. M. Groffman, L. E. Band, C. G. Boone, W. R. Burch Jr., C. S. B. Grimmond, J. Hom, J. C. Jenkins, N. L. Law, C. H. Nilon, R. V. Pouyat, K. Szlavecz, P. S. Warren, and M. A. Wilson. 2008. Beyond urban legends: an emerging framework of urban ecology, as illustrated by the Baltimore ecosystem study. BioScience 58:139-150. http:// dx.doi.org/10.1641/b580208

Puga-Caballero, A., I. MacGregor-Fors, and R. Ortega-Álvarez. 2014. Birds at the urban fringe: avian community shifts in different peri-urban ecotones of a megacity. Ecological Research 29:619-628. http://dx.doi.org/10.1007/s11284-014-1145-2
R Core Team. 2017. R: a language and environment for statistical computing. R Foundation for Statistical Computing, Vienna, Austria. [online] URL: http://www.R-project.org/

Ralph, C. J., S. Droege, and J. R. Sauer. 1995. Managing and monitoring birds using point counts: standards and applications. Pages 161-175 in C. J. Ralph, J. R. Sauer, and S. Droege, editors. Monitoring bird populations by point counts. General Technical Report PSW-GTR-149. U.S. Forest Service, Pacific Southwest Research Station, Albany, California, USA.

Ralph, C. J., G. R. Geupel, P. Pyle, T. E. Martin, and D. F. DeSante. 1993. Handbook of fieldmethods for monitoring landbirds. General Technical Report PSW-GTR-144. U.S. Forest Service, Pacific Southwest Research Station, Albany, California, USA. http://dx. doi.org/10.2737/psw-gtr-144

Robinson, R. A., G. M. Siriwardena, and H. Q. P. Crick. 2005. Size and trends of the House Sparrow Passer domesticus population in Great Britain. Ibis 147:552-562. http://dx.doi. org/10.1111/j.1474-919x.2005.00427.x

Š́ake, M., J. Riegert, and S. Grill. 2015. House Sparrows Passer domesticus and Tree Sparrows Passer montanus: fine-scale distribution, population densities, and habitat selection in a Central European city. Acta Ornithologica 50:221-232. http://dx. doi.org/10.3161/00016454AO2015.50.2.010

Sauer, J. R., J. E. Hines, J. E. Fallon, K. L. Pardieck, D. J. Ziolkowski Jr., W. A. Link. 2012. The North American Breeding Bird Survey, results and analysis 1966-2011. U.S. Geological Survey, Patuxent Wildlife Research Center, Laurel, Maryland, USA. [online] URL: https://www.mbr-pwrc.usgs.gov/bbs/ bbs2011.html

Seto, K. C., and N. Ramankutty. 2016. Hidden linkages between urbanization and food systems. Science 352:943-945. http://dx. doi.org/10.1126/science.aaf7439

Shaw, L. M., D. E. Chamberlain, and M. Evans. 2008. The House Sparrow Passer domesticus in urban areas: reviewing a possible link between post-decline distribution and human socioeconomic status. Journal of Ornithology 149:293-299. http://dx.doi. org/10.1007/s10336-008-0285-y

Shochat, E. 2004. Credit or debit? Resource input changes population dynamics of city-slicker birds. Oikos 106:622-626. http://dx.doi.org/10.1111/j.0030-1299.2004.13159.x

Summers-Smith, J. D. 2003. The decline of the House Sparrow: a review. British Birds 96:439-446.

Summers-Smith, J. D., D. A. Christie, and E. F. J. Garcia. 2017. House Sparrow (Passer domesticus). In J. del Hoyo, A. Elliott, J. Sargatal, D. A. Christie, and E. de Juana, editors. Handbook of the birds of the world alive. Lynx Edicions, Barcelona, Catalonia, Spain. [online] URL: http://www.hbw.com/node/60925

Therneau, T., B. Atkinson, and B. Ripley. 2015. rpart: recursive partitioning and regression trees. $R$ package version $4.1-8 . \mathrm{R}$ Foundation for Statistical Computing, Vienna, Austria. [online] URL: http://cran.r-project.org/package=rpart

Thomas, L., S. T. Buckland, E. A. Rexstad, J. L. Laake, S. Strindberg, S. L. Hedley, J. R. B. Bishop, T. A. Marques, and K. P. Burnham. 2010. Distance software: design and analysis of 
distance sampling surveys for estimating population size. Journal of Applied Ecology 47:5-14. http://dx.doi.org/10.1111/

j.1365-2664.2009.01737.x

Tratalos, J., R. A. Fuller, K. L. Evans, R. G. Davies, S. E. Newson, J. J. D. Greenwood, and K. J. Gaston. 2007. Bird densities are associated with household densities. Global Change Biology 13:1685-1695. http://dx.doi.org/10.1111/j.1365-2486.2007.01390.

$\mathrm{x}$

United Nations. 2015. World urbanization prospects: the 2014 Revision. General Technical Report ST/ESA/SER.A/366. Department of Economic and Social Affairs, Population Division. New York, New York, USA.

Van Rensburg, B. J., D. S. Peacock, and M. P. Robertson. 2009. Biotic homogenization and alien bird species along an urban gradient in South Africa. Landscape and Urban Planning 92:233-241. http://dx.doi.org/10.1016/j.landurbplan.2009.05.002

Wagner, H. O. 1959. Die Einwanderung des Haussperlings in Mexiko. Ethology 16:584-592. http://dx.doi.org/10.1111/j.1439-0310.1959. tb02075.x

White, J. G., M. J. Antos, J. A. Fitzsimons, and G. C. Palmer. 2005. Non-uniform bird assemblages in urban environments: the influence of streetscape vegetation. Landscape and Urban Planning 71:123-135. http://dx.doi.org/10.1016/j.landurbplan.2004.02.006 